\title{
P-86
}

\section{Antiproliferative and Antioxidant Activities of Quassia Borneensis Noot. On HL-60 Human Leukemia Cells}

\author{
Lim Kai Li ${ }^{1}$, Ahmad Rohi Ghazali ${ }^{1, *}$, Wan Marahaini Wan Razali ${ }^{1}$ and Julenah Ag Nuddin ${ }^{2}$ \\ ${ }^{I}$ Biomedical Science Programme, School of Diagnostic \& Applied Health Sciences, Faculty of Health Sciences, \\ Universiti Kebangsaan Malaysia; ${ }^{2}$ Faculty of Applied Sciences, Universiti Teknologi MARA, Sabah; \\ E-mail: rohi@fskb.ukm.my
}

The family of Simaroubaceae is known to contain quassinoids, a group of compounds that have been reported to possess numerous biological activities such as anticancer and antimalarial activities. This study was carried out to evaluate the inhibition of HL-60 cells proliferation and antioxidant capacity of various extracts from Quassia borneensis, an unexplored indigenous Simaroubaceae plant from Sabah. The bark and root of Q.borneensis were extracted by Soxhlet and maceration in methanol and further partitioned with hexane, chloroform and water. Twelve different extracts obtained were named as Q1 to Q12. The antiproliferative activity was determined by MTT assay while antioxidant capacity of Q.borneensis extracts was measured using Ferric Reducing Antioxidant Power (FRAP) assay with or without the presence of HL-60 cells. Among all the extracts, the highest antiproliferative activity on HL-60 cells was shown by bark Soxhlet chloroform extract (Q7) with the IC50 of $5.0 \mu \mathrm{g} / \mathrm{ml}$. Meanwhile, bark maceration chloroform extract (Q5) exhibited the highest antioxidant capacity with or without the presence of HL-60 cells, where the FRAP value were $125.45 \pm 9.10 \mu \mathrm{M} \mathrm{FeSO}{ }_{4} .7 \mathrm{H}_{2} \mathrm{O}$ and $181.55 \pm 3.45 \mu \mathrm{M} \mathrm{FeSO} .7 \mathrm{H}_{2} \mathrm{O}$ respectively. In conclusion, Q.borneensis possessed both antioxidant and antiproliferative activities on HL-60 cells where the highest activities were shown by chloroform extracts.

Keywords: Antiproliferative, antioxidant, Quassia borneensis Noot. 